\title{
Antidiabetic activity of seed extracts of Caesalpinia crista Linn. in experimental animals
}

\author{
Nakul Gupta ${ }^{1^{\star}}$, Ishan Sharma ${ }^{2}$, Meetu Agarwal ${ }^{1}$, Safhi M. Mohammed ${ }^{1}$, Prerna Chauhan $^{3}$, \\ Tarique Anwer ${ }^{1}$, Gyas Khan ${ }^{1}$ \\ ${ }^{1}$ Department of Pharmacology, College of Pharmacy, Jazan University, Jazan, Kingdom of Saudi Arabia (KSA). \\ ${ }^{2}$ Department of Pharmacology, Om Institute of Technology, Near Patanjali, Roorkee, Haridwar, India. \\ ${ }^{3}$ Department of Pharmacology, NIMS Institute of Pharmacy, NIMS University, Shobha Nagar, Jaipur, India, 303121.
}

Accepted 24 June, 2013

The present study was designed to evaluate antidiabetic activity of ethanolic and aqueous seed extracts of Caesalpinia crista linn. in streptozotocin (STZ) induced diabetes in 2 days old pups models. The seeds were collected, authenticated and shade dried. Shade dried seeds were then grinded into coarse powder and processed for further studies. Ethanolic and aqueous extracts were prepared and the preliminary phytochemical screening was performed. Ethanolic and aqueous both extracts were evaluated for the antidiabetic activity by using the streptozotocin induced diabetes in 2 days old pups model. After 3 months of streptozotocin administration, pups become diabetic and then further protocol was proceeded. Estimation of biological parameters like serum glucose, cholesterol and triglyceride were performed and body weight, water intake and food intake were also recorded after 3 weeks of treatment. Histopathological study was performed to study the structure of islets of pancreas in different group of animals. There was a significant decrease in the biological parameters that is, serum glucose, cholesterol and triglyceride when compared with diabetic untreated group after 3 weeks treatment plant extracts. Treatment with the extracts also affected the physical parameters like decrease in body weight, increase in demand of food intake and water intake when compared with diabetic untreated group. Histopathological study shows the changes in structure of islets of pancreas in different groups of animals. Hence, it can be concluded that in the above study, both ethanolic and aqueous seed extracts of $C$. crista linn. showed antidiabetic activity, but the aqueous extract of $C$. crista linn. showed more significant effect as compared to the ethanolic extract.

Key words: Diabetes mellitus, insulin resistance, streptozotocin (STZ), Caesalpinia crista linn., ethanolic and aqueous extracts.

\section{INTRODUCTION}

Diabetes mellitus (DM) is a disease characterized by chronic hyperglycaemia and glucosuria produced by an absolute or relative insufficiency of insulin (Andrew et al., 2000; Swanston et al., 1990). Hyperglycaemia and glucose intolerance are common manifestations of several types of hormonal disturbances or imbalances, of which the most important is diabetes mellitus (Forster,
1987). Type 2 DM accounts for as many as $90 \%$ of DM cases and is usually characterized by the presence of both insulin resistance and relative insulin deficiency. Insulin resistance is manifested by increased lipolysis and free fatty acid production, increased hepatic glucose production, and decreased skeletal muscle uptake of glucose. Pancreatic beta cell dysfunction is progressive 
and contributes to worsening blood glucose control over time. Type 2 DM occurs when a diabetogenic lifestyle (excessive calories, inadequate exercise, and obesity) is superimposed upon a susceptible genotype. (Barbara et al., 2006). This disease is the seventh leading cause of death in the world. Weight loss which is one of the clinical features of diabetes mellitus may be due to the degeneration of the adipocytes and muscle tissues to make up for the energy lost from the body due to frequent urination and over conversion of glycogen to glucose. Weight loss is a very serious issue in the management of diabetes mellitus (Reno and Leland, 1999; Zink and Chaffin, 1998).

Though different types of oral hypoglycemic agents are available along with insulin for the treatment of diabetes, there is an increased demand by patients to use natural products with antidiabetic activity (Venkatesh et al., 2003). Since time immemorial, patients with non-insulin dependent diabetes have been treated orally by folk medicine, with a variety of plant extracts. In India, a number of plants are mentioned in ancient literature (Ayurveda) for the treatment of diabetic conditions and others are antioxidants (Atef et al., 2013), antifungal (Cui et al., 2013), anxiolytic (Jitender et al., 2013) among others.

Caesalpinia crista linn. commonly known as kanchak, Latakranja is a medicinal plant belonging to the family Fabaceae, it is a widely growing plant throughout India and tropical countries of the world. Each and every part of the plant is claimed to possess some therapeutic property but seed kernel is the most widely used part all-over the world in various systems of medicine. The seeds are extremely bitter, commercially available in plenty at a very low cost and are widely used for a variety of disease, especially in cases of all types of fever including malaria. In Ayurveda, the seeds, leaves and bark of all three parts are used. The herb is useful for treatment of amenorrhoea, dysmenorrhoea, diabetes and intermittent fevers. Also, used as febrifuge, anthelmintic and expectorant (Das et al., 2010; Kirtikar and Basu, 2006; Handa and Kaul, 1996). Its anthelmintic activity (Abdul et al., 2007), nootropic activity (Kshirsagar, 2011), antioxidant and reactive oxygen species scavenging activity (Mandal et al., 2011), anticancer activity (Bodakhe et al., 2011), was already reported but the anti-diabetic activity has not been established yet. In the present study, we made an attempt to establish the anti-diabetic potential of ethanolic and aqueous seed extracts of $C$. crista linn.

\section{MATERIALS AND METHODS}

\section{Plant material}

Plant part (seed) were collected from the local market of Ropar (Punjab) and authenticated by Mr. Madan Pal, Executive Engineer, Horticulture Division No.2 (Chandigarh). The seeds were then shade dried and grinded and made a coarse powder and the coarse powder were used for further studies.

\section{Preparation of extract}

Extraction was done according to standard procedures using analytical grade solvents. For preparation of ethanolic extract, 300 gm powdered seed was taken in a pouch of filter paper and kept inside the soxhlet thistle then extracted with petroleum ether for 48$72 \mathrm{~h}$ for defatting after it reextracted with ethanol (99.99\%) for 48-72 h. Aqueous extract was separately prepared by maceration process. The extracts were then concentrated until dryness under reduced pressure and controlled temperature $\left(40-50^{\circ} \mathrm{C}\right)$. Then preliminary phytochemical screening was performed (Kokate et al., 2007). Percentage yield of extracts were calculated. The percentage yield of ethanolic and aqueous extracts was found to be 8.1 and $13.3 \%$. The $L_{50}$ determination of Caesalpinia crista seed extract was reported by Kshirsagar (2011) so a dose level of 100 $\mathrm{mg} / \mathrm{kg} \mathrm{b.w}$. is selected for the treatment.

\section{Preliminary phytochemical screening}

The extracts were subjected to preliminary phytochemical qualitative screening to evaluate the presence of various primary or secondary metabolites following standard procedures. In previous phytochemical studies, the presence of phytoconstituents such as flavonoids, tannins, proteins, alkaloids, saponins and triterpenoids were already reported (Gill et al., 2012).

\section{Experimental animals}

Evaluation of antidiabetic activity was done by using streptozotocin (STZ) induced diabetes in 2 days old pups model, in which 2 days old pups of Wistar rats were used and the animals were maintained under standard laboratory conditions with access to standard diet and water ad libitum. The experiment was carried out according to the Committee for the purpose of Control and Supervision of Experiments on Animals (CPCSEA) guidelines 2013. Before starting experimentation on test animals, permission of Institutional Animal Ethics Committee (IAEC) was obtained.

\section{Streptozotocin induced diabetes in 2 days old pups}

2 days old pups of Wistar rats weighing 7-10 gm were used to induce non-insulin dependent diabetes mellitus in this study. A freshly prepared solution of streptozotocin $(90 \mathrm{mg} / \mathrm{kg})$ in 0.1 $\mathrm{mol} / \mathrm{L}$ citrate buffer, $\mathrm{pH} 4.5$, was injected intraperitoneally to 2 days old pups. Vehicle control group of pups receive only saline. The animal were weaned at 30 days and after a period of 3 months they were checked for fasting glucose level to confirm the status of NIDDM. Animals showing fasting glucose level $>140 \mathrm{mg} / \mathrm{dl}$ were considered as diabetic. The pups that receive saline were considered as control animals (Gupta et al., 2011; Portha et al., 1994; Arulmozhiet et al. 2004).

\section{Treatment protocol}

The experimental animals were divided into five groups of six animals each. Group I was served as vehicle control and was treated with normal saline, Group II served as diabetic untreated group, Group III had diabetic animals treated with the ethanolic extract of $C$. crista linn. at a dose of $100 \mathrm{mg} / \mathrm{kg}$, Group IV had diabetic animals treated with aqueous extract of C. crista linn. at a dose of $100 \mathrm{mg} / \mathrm{kg}$ and Group V had diabetic animals treated with standard drug, glibenclamide, at a dose of $10 \mathrm{mg} / \mathrm{kg}$ body weight. Treatment was given daily for 3 weeks and at the end of 3 weeks of treatment the animals were kept 
on $12 \mathrm{~h}$ fasting and blood samples were collected from tail vein and analyzed for serum glucose, cholesterol and triglyceride level. Body weight, water intake and food intake were also being recorded.

\section{Histopathological studies}

For histopathological studies, animals were sacrificed at the end of 3 weeks treatment, after the collection of blood sample, pancreas was removed and washed with normal saline and preserved in $10 \%$ formalin, processed and stained with hematoxylin and eosin.

\section{Statistical analysis}

The significance of difference among the control group and various treated groups were analyzed by means of analysis of variance (ANOVA) with least significant difference (LSD) post hoc test was used to compare the group means and $\mathrm{P}<0.05$ was considered statistically significant. The experimental results are represented as mean \pm SEM (standard error mean). Statistical Package for Social Sciences (SPSS), for Windows (version 15.0, Chicago, IL, USA) was used for statistical analysis.

\section{RESULT}

The preliminary phytochemical screening of the ethanolic and aqueous extracts of the plant $C$. crista linn. showed the presence of phytoconstituents such as flavonoids, tannins, proteins, alkaloids, carbohydrates reducing sugars, phytosterols, saponins and triterpenoids. Pups that received saline were considered as control animals, ethanolic, and aqueous seed extracts of C. crista linn. were used for the experiment and glibenclamide (10 $\mathrm{mg} / \mathrm{kg}$ b.w. p.o.) for three weeks was used as standard drug for the group $\mathrm{V}$.

Effect of ethanolic and aqueous seed extracts of Caesalpinia crista linn. on the serum level of diabetic rats is shown in Table 1. STZ at a dose of $90 \mathrm{mg} / \mathrm{kg}$ caused elevation of serum glucose (180.30 \pm 0.689$)$, serum cholesterol $(81.60 \pm 0.240)$ and serum triglycerides $(123.40 \pm 0.712)$ in diabetic untreated group when compared with vehicle control groups levels of serum glucose $(82.43 \pm 0.684)$, cholesterol $(50.83 \pm 0.763)$ and triglyceride $(50.92 \pm 0.265)$. Treatment with seed extracts of C. crista linn. (ethanolic and aqueous) significantly reduced the level of these biological parameters. But the maximum effect was shown by aqueous seed extract of C. crista linn. at a dose of $100 \mathrm{mg} / \mathrm{kg}$, which decrease the levels of serum glucose $(111.70 \pm 0.794)$, cholesterol $(55.50 \pm 0.595)$ and triglyceride $(61.18 \pm 0.385)$ when compared with diabetic untreated group.

Effect of ethanolic and aqueous seed extracts of $C$. crista linn. on body weight, water intake and food intake of diabetic rats is shown in Table 2. STZ (90 mg/kg: i.p.) treatment led to a significant reduction in body weight $(154.8 \pm 0.735)$ and increase in water intake $(54.9 \pm 0.436)$ and food intake (37.3 \pm 0.232$)$ of diabetic untreated group, when compared with vehicle control groups body weight (209.8 \pm 0.684$)$, water intake $(39.9 \pm 0.366)$ and food intake (17.8 \pm 0.386$)$. Treatment with the ethanolic and aqueous seed extracts of $C$. crista linn. significantly reversed the reduced body weight and increased demand of water and food intake when compared with diabetic untreated group. But the maximum effect was shown by the aqueous seed extract of $C$. crista linn. which reversed the reduced body weight $(185.9 \pm 0.737)$, and increased demand of water intake $(43.0 \pm 0.578)$ and food intake $(23.3 \pm 0.320)$ when compared with diabetic untreated group.

Difference in the effects of induction, standard drug and test drug can be easily seen in histopathology of pancreas of experimental animals. In pancreatic sections of diabetic rats (Group-II) (Figure 1b), the islets were less intact and their shape was destroyed as compared to Group-I with infiltration of lymphocytes (Figure 1a). In standard group in which diabetic rats treated with glibenclamide, islets resemble to vehicle control rat islets having normal round and structural intactness with their nucleus (Figure 1c). In C. crista linn. aqueous extract treated rats (Figure 1d), the islets were normal round but enlarged in size and having intact nucleus which was similar to the pancreas of vehicle control groups and in $C$. crista linn. (Figure 1e) ethanolic extract treated rats whose islets of pancreas were normal but enlarged in size and less improved then aqueous extract group of $C$. crista linn.

\section{DISCUSSION}

There was a significant decrease in the biological parameters that is, serum glucose, cholesterol and triglyceride when compared with diabetic untreated group after 3 weeks treatment with $C$. crista linn. extracts. Treatment with the extracts also affect the physical parameters like decrease body weight, increase demand of food intake and water intake when compared with diabetic untreated group. Histopathological study also showed changes in structure of islets of pancreas in different groups of animals giving strength to the results observed by the physical and biological parameters.

Diabetes mellitus, an endocrine and metabolic disorder characterized by chronic hyperglycemia produces multiple biochemical impairments and oxidative stress especially an increased susceptibility to lipid peroxidation that play role in the progression of the symptoms of diabetes (Giugliano et al., 1996). Several hypotheses have been postulated to explain the development of free radicals in diabetes which include auto oxidation of glucose, enzymatic and non-enzymatic glycation of proteins with increased formation of glucose derived advanced glycosylation end products (AGEs), enhanced glucose flux through polyol pathway (Oberlay, 1988) and reduction of antioxidant defence (Lipinski, 2001). Despite progress in the management of diabetes mellitus by synthetic drugs, most of these drugs have side effects in 
Table 1. Effect of extracts of Caesalpinia crista linn. on serum profile of streptozotocin (STZ) induced diabetic rats (2 days old pups).

\begin{tabular}{|c|c|c|c|c|}
\hline Group & Treatment & S. glucose & S. cholesterol & S. triglycerides \\
\hline I & Vehicle control & $82.4 \pm 0.684$ & $50.8 \pm 0.763$ & $50.9 \pm 0.265$ \\
\hline II & Diabetic untreated & $180.3 \pm 0.689^{*}$ & $81.6 \pm 0.240^{*}$ & $123.4 \pm 0.712^{*}$ \\
\hline III & Diabetic treated with CCEE $100 \mathrm{mg}$ & $119.0 \pm 0.562^{\star * *}$ & $61.4 \pm 0.530^{\star \star \star}$ & $66.0 \pm 0.774^{\star \star *}$ \\
\hline IV & Diabetic treated with CCAE $100 \mathrm{mg}$ & $111.7 \pm 0.794^{\star \star *}$ & $55.5 \pm 0.595^{\star * *}$ & $61.1 \pm 0.385^{\star * *}$ \\
\hline $\mathrm{V}$ & Diabetic treated with $10 \mathrm{mg} / \mathrm{kg}$ of glibenclamide & $92.0 \pm 0.801^{* * *}$ & $50.9 \pm 0.620^{\star * *}$ & $55.1 \pm 0.486^{* \star *}$ \\
\hline
\end{tabular}

Values are expressed as mean $\pm \operatorname{SEM}(n=6)$. *, Significantly different from vehicle control $(P<0.05)$; ${ }^{* * *}$, significantly different when compared with diabetic untreated $(P<0.05)$.

Table 2. Effect of extracts of Caesalpinia crista linn. in streptozotocin (STZ) induced diabetic rats (2 days old pups).

\begin{tabular}{|c|c|c|c|c|}
\hline Group & Treatment & $\begin{array}{c}\text { Average Body } \\
\text { weight (grams/rat) }\end{array}$ & $\begin{array}{c}\text { Water intake } \\
\text { (ml/rat/day) }\end{array}$ & $\begin{array}{c}\text { Food intake } \\
\text { (grams/rat/day) }\end{array}$ \\
\hline 1 & Vehicle control & $209.8 \pm 0.684$ & $39.9 \pm 0.366$ & $17.8 \pm 0.386$ \\
\hline ॥ & Diabetic untreated & $154.8 \pm 0.735^{\star}$ & $54.9 \pm 0.436$ * & $37.3 \pm 0.232^{*}$ \\
\hline III & Diabetic treated with CCEE $100 \mathrm{mg}$ & $179.3 \pm 0.794^{* * *}$ & $45.6 \pm 0.316^{* * *}$ & $26.3 \pm 0.263^{\star * *}$ \\
\hline IV & Diabetic rats treated with CCAE $100 \mathrm{mg}$ & $185.9 \pm 0.737^{\star \star *}$ & $43.0 \pm 0.578^{\star * *}$ & $23.3 \pm 0.320^{\star \star *}$ \\
\hline $\mathrm{V}$ & Diabetic rats treated with $10 \mathrm{mg} / \mathrm{kg}$ of glibenclamide & $197.4 \pm 0.721^{* * *}$ & $41.3 \pm 0.650^{* * *}$ & $20.0 \pm 0.474^{\star * *}$ \\
\hline
\end{tabular}

Values are expressed as mean \pm SEM $(n=6)$; *, significantly different from vehicle control $(P<0.05)$; ***, significantly different from diabetic untreated $(P<0.05)$.
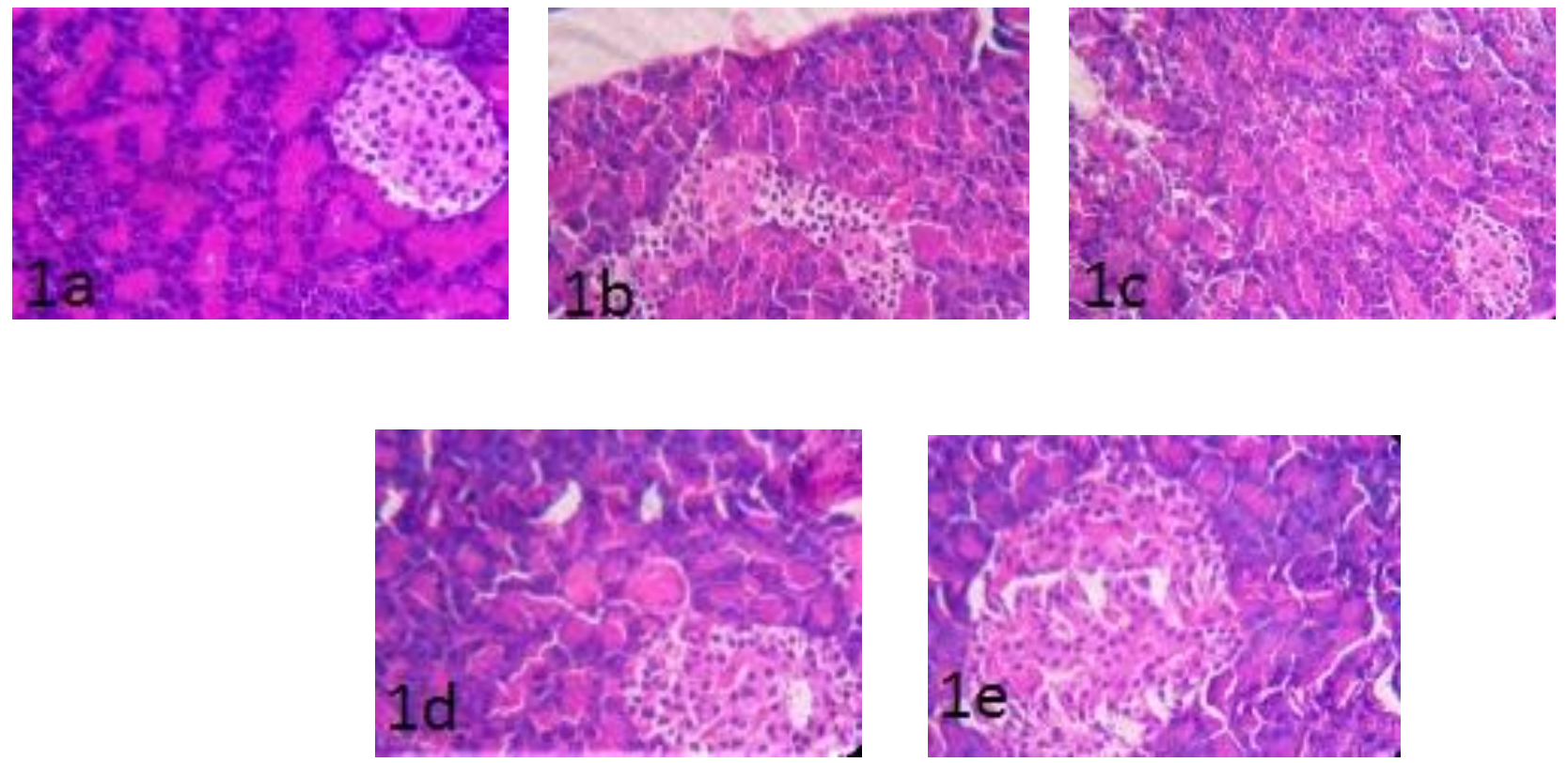

Figure 1. a, Vehicle control islets with normal round and structural intactness with their nucleus; $b$, diabetic untreated rat islets damaged and shrunken in size; c, effect of glibenclamide (10 mg/kg b.w. p.o.) on islets in pancreas of streptozotocin (STZ) induced diabetic rats resembling with vehicle control rat islets with normal round nucleus and structural intactness; $d$, effect of aqueous extracts of Caesalpinia crista linn. (100 mg/kg b.w. p.o.) on islets in pancreas of STZ induced diabetic rats showing round structure of islets, and intact nucleus; e, effect of ethanolic extracts of $C$. crista linn. (100 mg/kg b.w. p.o.) on islets in pancreas of STZ induced diabetic rats showing normal structure of islets but enlarged in size.

the long run. So, the search for improved and safe natural antidiabetic agents is on-going and World Health
Organization has also recommended the development of herbal medicine in this concern (Schmincke, 2003). 
In all diabetic patients, treatment should aim to lower blood glucose to near normal level. The present investigation fulfils this statement by producing a significant fall in blood glucose levels. Flavonoid and terpenes possess antidiabetic action. Effect of the flavonoids on pancreatic $\beta$-cells leading to their proliferation and secretion of more insulin, the mechanism by which they reduced hyperglycaemia caused by streptozotocin in diabetic rats, was already reported (Rajalakshmi et al., 2009; Patil et al., 2011).

STZ is well known for destroying insulin secreting $\beta$ cells in the islets of Langerhans (Fisher, 1985) and has been extensively used in induction of diabetes mellitus in animals (Tialve, 1983). Experimental evidence has demonstrated that some of its deleterious effects are attributable to induction of metabolic processes, which lead on to an increase in the generation of reactive oxygen species (ROS) (Chen et al., 1990). Apart from production of ROS, STZ also inhibits free radical scavenger-enzymes (Kroncke et al., 1995).

The present study was an effort to investigate the effect of seed extracts of C. crista linn. on normal and streptozotocin-induced diabetic rats. Similar effects in streptozotocin-treated diabetic animals were reported by pancreas tonic (Rao et al., 1998), ephedrine (Xiu et al., 2001), Tinospora cordifolia stem extracts (Rajalakshmi et al., 2009) and Gymnema sylvestre leaf extracts (Shanmugasundaram et al., 1990). In the current studies, the damage of pancreas in streptazotocin-treated diabetic control rats and regeneration of $\beta$-cells by glibenclamide was observed. The comparable regeneration was also shown by ethanolic and petroleum ether extracts of $C$. crista linn. and showed significant $(p \leq 0.5)$ decrease in the serum glucose, cholesterol and triglyceride level and also reversed the reduced body weight and increased demand of food and water intake when compared with the diabetic untreated group. The data obtained from this study indicates that the extracts of the plant $C$. crista linn. are capable of exhibiting significant antihyperglycemic activities in diabetic rats. These extracts showed improvement in parameters like body weight and serum profile as well as regeneration of $\beta$-cells of pancreas and so might be valuable in diabetes treatment.

\section{ABBREVIATIONS}

DM, Diabetes mellitus; STZ, streptozotocin; AGEs, advanced glycosylation end products; ROS, reactive oxygen species

\section{REFERENCES}

Abdul J, Muhammad AZ, Zafar I, Muhammad Y, Asim S (2007). Anthelmintic activity of Chenopodium album (L.) and Caesalpinia crista (L.) against trichostrongylid nematodes of sheep. J. Ethnopharmacol. 114(1):86-91.

Andrew IR, Belinda EC, Helen H, Michael DE, Scott CB (2000).
Microvascular Complications in Cystic fibrosis-Related Diabetes mellitus: a case report. J. Pancreas. 14:208-210.

Arulmozhi DK, Veeranjaneyulu A, Bodhankar SL (2004). "Neonatal streptozotocin-induced rat model of Type 2 diabetes mellitus: A glance" Indian J. Pharmacol. 36(4):217-221.

Atef MMAttia, Fatma AAI, Ghada MN, Samir WA (2013). Antioxidant effects of ginger (Zingiber officinale Roscoe) against lead acetateinduced hepatotoxicity in rats. Afr. J. Pharm. Pharmacol. 7(20):12131219.

Barbara G. Wells, Dipiro JT, Schwinghammer TL, Hamilton CW (2006). Pharmacotherapy Handbook, 6th ed. New York: Mc Graw-Hill Co. p.284.

Bodakhe SH, Agrawal A, Agrawal A, Shinde N, Namdeo KP (2011). Anticancer Study On Alcoholic Extract Of Caesalpinia crista Root Bark Extract. J. Pharm. Res. Opin. 1(4):126-128.

Chen YT, Zheng RL, Jia ZJ, Ju Y (1990). Flavonoids as superoxide scavengers and antioxidants. Free Radic. Biol. Med. 9:19-20.

CPCSEA (2003). Guidelines for laboratory animal facility. Indian J. Pharmacol. 35(4):257-274.

Cui T, Qin W, Zhong-Qiong Y, Li-Jun Z, Ren-Yong J, Jiao X (2013). Antifungal activity of essential oil from Cinnamomum longepaniculatum leaves against three dermatophytes in vitro. Afr. J. Pharm. Pharmacol. 7(19):1148-1152.

Das B, Srinivas Y, Sudhakar C, Mahender I, Laxminarayan K (2010). New diterpenoids from Caesalpinia crista species and their cytotoxic activity. Bioorg. Med. Chem. Lett. 20:2847-50

Fisher J (1985). Drugs and chemicals that produce diabetes. Trends Pharmacol. Sci. 6:72-75.

Forster D. Diabetes mellitus (1987). In: Braunwal's editor. Harrison's Principles of Internal Medicine, 11th ed. New York: Mc Graw-Hill Co. p.1778.

Gill NS, Kaur R, Arora R, Bali M (2012). Phytochemical investigation of Caesalpinia crista seed extract for their therapeutic potential. Res. J. Med. Plants 6(1):100-107.

Giugliano D, Ceriello A, Paolisso G (1996). Oxidative stress and diabetic vascular complications. Diabetics Care 19:257-567.

Gupta N, Agarwal M, Bhatia V, Sharma RK, Narang E (2011). A Comparative antidiabetic and hypoglycaemic activity of the crude alcoholic extract of the plant leucas aspara and seed of Pithecellobium begminum in rats. IJRAP 2(1):275-280.

Handa SS, Kaul MK (1996). Supplement to cultivation and utilization of medicinal plants. pp. 727-739.

Jitender KM, Dayanand HG, Sourabh J (2013). Evaluation of hydroalcoholic extract of leaves of Boerhaavia diffusa for anxiolytic activity in rats. Afr. J. Pharm. Pharmacol. 7(18):1071-1074.

Kirtikar, Basu (2006). Indian Medicinal Plants. Il. pp. 842-845

Kokate CK, Gokhale SB, Purohit AP (2007). In: Pharmacognosy. $39^{\text {th }}$ edition. Nirali Prakashan. pp.106-109.

Kroncke KD, Fehsel K, Sommer A, Rodriguez ML, Kolb-Bachofen V (1995). Nitric oxide generation during cellular metabolization of the diabetogenic N-methyl-nitroso-urea: Streptozotocin contributes to islet cell DNA damage. Biol. Chem. Hoppe-Seyler 376:179-185.

Kshirsagar SN (2011). Nootropic Activity of dried Seed Kernels of Caesalpinia crista Linn against Scopolamine induced Amnesia in Mice. Int. J. Pharm. Tech. Res. 3(1):104-109.

Lipinski B (2001). Pathophysiology of oxidative stress in diabetes mellitus. J. Diabetics Complications 15:203-210.

Mandal S, Bibhabasu H, Rhitajit S, Santanu B, Mandal N (2011). Assessment of the Antioxidant and Reactive Oxygen Species Scavenging Activity of Methanolic Extract of Caesalpinia crista Leaf. Hindawi Publishing Corporation: pp. 114-118.

Oberlay LW (1988). Free radicals and diabetes. Free Radic. Biol. Med. 5:113-124.

Patil A, Nirmal S, Pattan S, Tambe V, Tare M (2011). Antidiabetic effect of polyherbal combinations in STZ induced diabetes involve inhibition of $\alpha$-amylase and $\alpha$-glucosidase with amelioration of lipid profile. Phytopharmacology 22(1):46-57.

Portha B, Giroix MH, Serradas P, Morin L, Saulnier C, Bailbe D. (1994), Glucose refractoriness of pancreatic beta-cells in rat models of noninsulin dependent diabetes. Diabetic Metab. 1994; 20(2):108-15.

Rajalakshmi M, Eliza J, Cecilia Edel P, Nirmala A, Daisy P (2009). Anti-diabetic properties of Tinospora cordifolia stem extracts on 
streptozotocin- induced diabetic rats. Afr. J. Pharm. Pharmacol. 3(5):171-180

Rao RM, Salem FA, Gleason JI (1998). Antidiabetic effects of a dietary supplement 'Pancreas Tonic'. J. National Med Assoc. 90:614-618.

Reno J, Leland J. (1999). Heavy meddling (news). Newsweek.134:5657.

Schmincke KH (2003). Medicinal Plants for forest conservation and healthcare. Non- Wood Forest Products 11. Food and Agriculture Organization of the United Nation.

Shanmugasundaram ER, Gopinath KL, Radha Shanmugasundaram K, Rajendran VM (1990). Possible regeneration of the islets of Langerhans in streptozotocin- diabetic rats given Gymnema sylvestre leaf extracts. J. Ethnopharmacol. 30:265-279.

Swanston FSK, Day C, Bailey CJ, Flatt PR (1990). Traditional plant treatments for diabetes Studies in normal and Streptozotocin diabetic mice. Diabetologia 33:462-464.
Tialve H (1983). Streptozotocin: distribution, metabolism and mechanisms of action. Uppsala J. Med. Sci. 39:145-147.

Venkatesh S, Reddy GD, Reddy BM, Ramesh M, Apparao AVN (2003). Antihyperglycemic activity of Caralluma attenuate. Fitoterapia 74:274279.

Xiu LM, Miura AB, Yamamoto K, Kobayashi T, Song QH, Kitamura $H$, Cyong JC (2001). Pancreatic islet regeneration by ephedrine in mice with streptozotocin-induced diabetes. Am. J. Chin. Med. 29:493-500.

Zink T, Chaffin JH (1998). "health" products: What family physicians need to know. Am. Fam. Physician 58:1133-1140. 